\title{
A Quiet Man: J.M. Coetzee as an Author of the Works of Isolation
}

\author{
Sheeba Anjum \\ Department of English, Swami Keshvanand Institute of Technology, Management \& Gramothan, Jaipur- \\ 302017(INDIA) \\ Email: sheeba.anjum@skit.ac.in \\ Received 29.09.2021, received in revised form 13.10.2021, accepted 13.10.2021 \\ doi: 10.47904/IJSKIT.11.2.2021.85-86
}

\begin{abstract}
The paper explores J.M. Coetzee's position as a writer of the works of Isolation. Isolation is a recurrent theme in his works. He presents the idea of Isolation uniquely because all are born alone and will die alone. The paper deals with a few of his significant works- In the Heart of the Country (1977), Disgrace (1999), and Slow Man (2005), all highlight the role of Isolation. The protagonists of these works are lonely and frustrated beings because they face acute and abject Isolation in their lives. Therefore, the paper attempts to discuss Isolation in the lives of the characters of the selected novels and how it can be a quest for identity.
\end{abstract}

Keywords- Isolation, Existentialism, identity, postapartheid

\section{INTRODUCTION}

John Maxwell Coetzee is a noble laureate from South Africa, now living in Australia. He is the first author to win the prestigious Booker Prize twice in his literary career. Born on Feb 9, 1940, in Cape Town, South Africa, Coetzee is one of the most acclaimed authors of the twenty-first century. In his fictional memoirs, he spent his early childhood on the Karoo farm and talked about his childhood experience in Boyhood, Youth, and summertime. Being a white South African, Coetzee, since his childhood, faced identity problems and felt secluded in his native country. He explains his trauma in his memoir in the following words:

"Because they speak English at home because he always comes first in English at school, he thinks of himself as English. Though his surname is Afrikaans, though his father is more Afrikaans than English, though he speaks Afrikaans without an English accent, he could not pass for a moment as an Afrikaner"[1].

The difficult childhood and the political unrest in the country contributed to his reluctant and reserved behavior. One of the journalists has remarked that he has seldom seen Coetzee smile. The post-apartheid era left an irreparable mark on his identity; as a result, he shifted to Australia in 2002 and is now a natural citizen of Australia. Coetzee's works reflect the pain of being isolated in one's life even while living in one's own country. For him, literature in South Africa is a "literature of bondage." We can put his works into two categories- South African and Australian. Almost all his works have Isolation as a poignant theme depicting the author's Isolation as well. In the Heart of the Country and Disgrace belong to South African works, while Slow Man is considered his first full-fledged Australian novel.

The theme of Isolation is all-pervading in Coetzee's works, reflecting in his philosophy of life. Like his precursor Samuel Beckett, firmly believes that Isolation and its various forms occupy an individual's life, sometimes intentionally and at other times unintentionally. Coetzee has also categorized his beliefs as personal Isolation, geographical Isolation, and Social Isolation. He openly accepts and conveys his feelings in Doubling the Point:

"I am not a herald of community or anything else...I am someone who has intimations of freedom ( as every chained prisoner has) and constructs representations which are shadows themselves - of people slipping their chains and turning their faces to the light."'[2]

The above statement clearly shows that he is a highly private person who doesn't want to be in the limelight. For this attitude, he has faced a lot of criticism as well. Throughout his novels, critical essays, and interviews, he has referred to other writers such as Beckett, Kafka, Barthes, and Camus. Out of these, Samuel Beckett is one of his most prominent literary influences. Beckett, too believed in the utility of Isolation as he says, "Despite our external attempts to join, to share our lives, we are all isolated in our facticity. Isolation is a fact; connection is an illusion" [3].

The paper discusses three novels with Isolation as a prominent theme. Magda, David Lurie, and Paul Rayment are the main characters described as lonely and frustrated people in the novels. The Heart of the Country was published in 1977 with Isolation as the central theme. Dominic head's remark is apt to quote as he asserts, "Written at a time of increasing international isolation for South Africa, this is an inward-looking novel, a point emphasized by the South African edition."[4]. Magda is the central character in the novel. She is a lonely spinster who lives with her father on an isolated farm. She does not share a cordial relationship with her father and imagines even killing her. Coetzee describes the blank relationship of a father and daughter in a colonized setting. Magda describes her situation in these words:

"I am incomplete; I am a being with a hole inside me, I signify something, I do not know what, I am dumb, I 
stare out through a sheet of glass into a darkness that is complete, that lives in itself, bats, bushes, predators and all, that does not regard me, that is blind, that does not signify but merely is" [5].

This interior monologue of Magda confirms the psychological void in her life, which eventually turns into her physical Isolation. It is the second work of Coetzee after Dusklands and is undoubtedly an "extension to Coetzee's concern in Dusklands.

Disgrace (1999) is Coetzee's most controversial and infamous work to date. It brought international acclaim for the author, and he became the first living author to win the second Booker of his career. The story of Disgrace revolves around English professor David Lurie and his daughter Lucy Lurie. Abstraction and Isolation are the most prominent themes of the novel, and the publication of this work established Coetzee as the author of Isolation. David Lurie is a womanizer and has sexual contact with prostitutes. Two-time divorcee, he cannot tolerate the loneliness of his life and therefore visits Soraya, a Muslim prostitute. When Soraya leaves him, he cannot bear it and gets infatuated with one of his students, bringing his ' Disgrace.' David Lurie cannot adjust and accept his mistake before the committee hearing; therefore has to leave the university. The novel's focus then shifts to the countryside. Coetzee has employed the plaasroman technique to depict the isolated setting. Lucy Lurie's entry in the story as a solitary woman, living and managing all on her own, is indeed a quality missing in the women of post-apartheid South Africa.

There are a lot of similarities between Magda and Lucy. Both are spinsters, lonely, and do not have a cordial relation with their fathers. But the most important and common thing is the rape of both. Coetzee dealt with the issue of rape in both works to particularly highlight the plight of women in the postapartheid era. Coetzee as an author of post-colonial writing, very emphatically shows the disturbed female subject in his works. Lucy in Disgrace tells her father, "Objectively I am a woman alone. I have no brothers. I have a father, but he is far away and anyhow powerless in the terms that matter here. To whom can I turn for protection, for patronage?" [6]

Magda, too laments her abject Isolation throughout the text. The mental and physical loneliness which she felt after her father's death led to dangerous consequences. Both Lucy and Magda are victims of geographical Isolation also. The remote and boring farm setting further aggravates their sense of Isolation. Coetzee's sense of pain belonging to his native place reflects in his works. He was never able to associate himself with the tag of a South African writer. Moreover, his continued criticism of the post-apartheid era could be held responsible for leaving South Africa and moving to Australia in 2002.

Slow Man (2005) is the first Australian novel of Coetzee with Isolation and disability as the central theme. Paul Rayment is a lonely immigrant who met with an accident and lost his leg. A disabled man and a childless divorcee, Rayment thinks he is hollow from the core after his accident. He cannot accept his fractured identity, and therefore, Coetzee has shown that physical disability can cause acute frustration, especially when one is suffering from Isolation. The novel revolves around the theme of Isolation with physical deformity as one of its forms. It seems to be the specialty of Coetzee that he highlights the role of Isolation through various forms. Dorfman observes, "Human contemporary condition and very bleak landscape of the human soul with radiance, luminosity, and tenderness" is characteristic of Coetzee's writings. [7]

\section{CONCLUSION}

The analysis of the selected works brings to light the role of Isolation as a social truth. The isolated characters of Coetzee draw the readers' attention to a kind of disguise in which his works exist, as explained by Blanchot that his works "subsists by itself." [8]. The novels explicitly show broken relationships causing and imposing loneliness upon the characters. A noticeable characteristic of Coetzee's work that came out from this is that every man and woman is solitary, sometimes by choice and sometimes by the situation. It can vary according to place, culture, gender but is an inescapable reality in one's life.

\section{REFERENCES}

[1] Coetzee, J.M. Boyhood: Scenes From Provincial Life. London: Secker and Warburg, 1997.

[2] Coetzee, J.M. Doubling the Point, edited by David Attwell. Harvard UP, 1992

[3] The New York Times Archives, Aug 3, 1997.http//archives.nytimes.com

[4] Head, Dominic, J. M. Coetzee. Cambridge: Cambridge University Press, 1997.

[5] Coetzee, J.M. In the Heart of the Country. London: Secker and Warburg, 1977

[6] Coetzee, J.M. Disgrace, Viking Penguin, 1999.

[7] Dorfman, Ariel. "Interview with Ariel Dorfman" http://www.pbs.org/newshourbb/entertainment/julydec03/coetzee_10-02.html

[8] Blanchot, Maurice. The Space of Literature. Translated by Ann Smock, University of Nebraska Press, 1982 